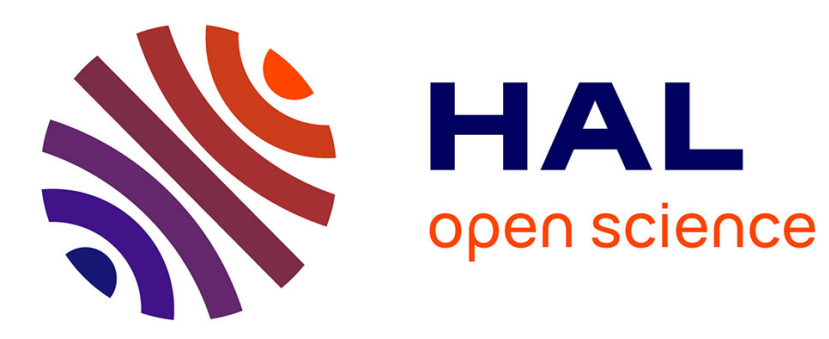

\title{
Phenysilane and Silicon Tetraacetate: Versatile Promotors for Amide Synthesis
}

Eléonore Morisset, Aurélien Chardon, Jacques Rouden, Jerome Blanchet

\section{To cite this version:}

Eléonore Morisset, Aurélien Chardon, Jacques Rouden, Jerome Blanchet. Phenysilane and Silicon Tetraacetate: Versatile Promotors for Amide Synthesis. European Journal of Organic Chemistry, 2020, 2020 (3), pp.388-392. 10.1002/ejoc.201901660 . hal-02962274

\section{HAL Id: hal-02962274}

\section{https://hal-normandie-univ.archives-ouvertes.fr/hal-02962274}

Submitted on 9 Oct 2020

HAL is a multi-disciplinary open access archive for the deposit and dissemination of scientific research documents, whether they are published or not. The documents may come from teaching and research institutions in France or abroad, or from public or private research centers.
L'archive ouverte pluridisciplinaire HAL, est destinée au dépôt et à la diffusion de documents scientifiques de niveau recherche, publiés ou non, émanant des établissements d'enseignement et de recherche français ou étrangers, des laboratoires publics ou privés. 


\title{
Phenysilane and Silicon Tetraacetate: Versatile Promotors for Amide Synthesis.
}

\author{
Eléonore Morisset ${ }^{[\mathrm{a}]}$, Aurélien Chardon ${ }^{[\mathrm{a}]}$, Jacques Rouden ${ }^{[\mathrm{a}]}$ and Jérôme Blanchet ${ }^{\star[a]}$
}

\begin{abstract}
Phenylsilane was reevaluated as a useful coupling reagent for amide synthesis. At room temperature, a wide range of amides and peptides were obtained in good to excellent yields (up to $99 \%$ ). For the first time, Weinreb amides synthesis mediated by a hydrosilane were also documented. Comparative experiments with various acetoxysilanes suggested the involvement of a phenyltriacyloxysilane. From this mechanistic study, silicon tetracetate was shown as an efficient amine acylating agent.
\end{abstract}

\section{Introduction}

Amide bonds are ubiquitous in chemical science. From natural products to polymers, amide is one of the most popular and useful functional groups in chemistry. ${ }^{[1]}$ In biological systems, the importance of the amide bond lies in sustaining life by linking amino acids together thus forming proteins. ${ }^{[2]}$ Therefore, it is not surprising that amide bond formation is the most frequently performed transformations in the chemist's toolbox. ${ }^{[3]}$ The use of chlorinating, diimide or onium based coupling reagents $\left(\mathrm{SOCl}_{2}\right.$, DCC, EDCI, HATU...) are highly predictable methodologies to combine carboxylic acids and amines. ${ }^{[4]}$ Nevertheless, some issues are still associated with these reagents, related to partial racemization, waste, toxicity or chemoselectivity. ${ }^{[5]}$ Within this context, novel methodologies for amides and peptides synthesis are in great demand and stimulated global efforts in the area of amide synthesis. ${ }^{[6]}$

Alongside tremendous progresses in metal- and boron-catalyzed methodologies $^{[7,8]}$, there has been a steep rise in the development and implementation of silicon-based reagents as a useful alternative to recently developed coupling reagents. ${ }^{[9]}$ Pioneered by Chan in $1969,{ }^{[10 a, b]}$ the use of silicon active reagents derived from $\mathrm{SiCl}_{4}$ was later investigated by Liskamp $\left(\mathrm{Me}_{2} \mathrm{SiCl}_{2}\right)$ and Mukaiyama to culminate recently with the development of a 9-silafluorenyl dichloride by Charette (Figure 1). ${ }^{[10 \mathrm{c}-\mathrm{h}]}$ Although a useful scope was accomplished with the later this methodology required a large excess of a Brønsted base as hydrogen chloride scavenger. This resulted in large chemical wastes and enantiomeric erosion of substrate, notably in the presence of sensitive phenylglycine derivatives.

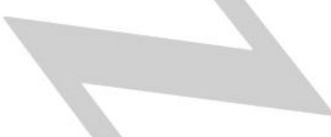

[a] E. Morisset, Dr A. Chardon, Pr. J. Rouden, Dr J. Blanchet Laboratoire de Chimie Moléculaire et Thio-organique, Normandie Univ, ENSICAEN, UNICAEN, CNRS, 14000 Caen, France. jerome.blanchet@ensicaen.fr. https://www.lcmt.ensicaen.fr/cv-jerome-blanchet/ Supporting information for this article is given via a link at the end of the document.

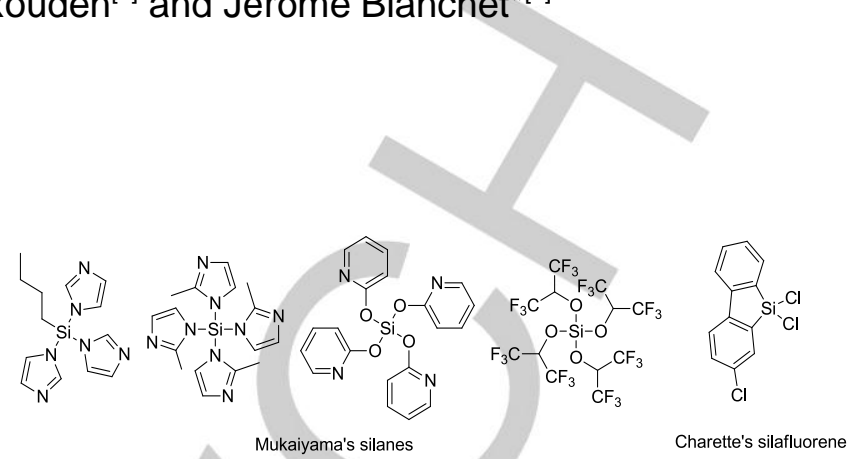

Figure 1. Reported silicon coupling agents.

In 2018, Braddock reported a simple and efficient procedure however relying on highly toxic tetramethylorthosilicate (TMOS). ${ }^{[11]}$

Within this framework, hydrosilanes are appealing considering low toxicity and that hydrogen gas and silanols are expected as only side products. However, the use of hydrosilanes appears underinvestigated: only two reports mention it so far. In 2006, phenylsilane $\left(\mathrm{PhSiH}_{3}\right)$ was examined as a mild coupling reagent using a high-throughput screening of various amines and carboxylic acids. ${ }^{[12]}$ Driven by initial success in homogeneous solution, further solid phase syntheses were carried out using large excess of phenylsilane at room temperature. ${ }^{[13]}$

Later, Charette documented diphenylsilane $\left(\mathrm{Ph}_{2} \mathrm{SiH}_{2}\right)$ as an effective coupling reagent for amide and peptide synthesis. ${ }^{[14]}$ Under the reported conditions (DMAP 0.5 equiv., DIPEA 1 equiv., acetonitrile, $80^{\circ} \mathrm{C}$ ), an array of dipeptides were synthesized albeit considerable epimerization was observed in the case of $N$ Boc-phenylglycine (e.r. 61:39). Moreover, Fmoc protecting group was found incompatible with the reported reaction conditions. Surprisingly, upon screening the nature of the hydrosilane, phenylsilane was found less reactive. Intrigued by this result, we decided to reassess phenylsilane potential as coupling reagent for peptide and Weinreb amide synthesis.

\section{Results and Discussion}

Our investigation began by examining a model reaction involving morpholine and phenylacetic acid. A stoichiometric amount of both partners in methylene chloride afforded a promising $50 \%$ yield after one hour at room temperature (Table 1, entry 1 ). 
Table 1. Optimization of amide synthesis with phenylsilane.

\begin{tabular}{cccc} 
& $1: 2: \mathrm{PhSiH}_{3}$ & $\mathrm{t}$ & $50 \%$ \\
\hline Entry & $1: 1: 1$ & $1 \mathrm{~h}$ & $39 \%$ \\
\hline 1 & $1: 1: 3$ & $1 \mathrm{~h}$ & $68 \%$ \\
3 & $1: 1: 1$ & $5 \mathrm{~h}$ & $74 \%$ \\
4 & $1: 1.5: 1.5$ & $5 \mathrm{~h}$ & $84 \%$ \\
5 & $1.5: 1: 1.5$ & $2 \mathrm{~h}$ & $100 \%$ \\
7 & $2: 1: 1.5$ & $2 \mathrm{~h}$ & $100 \%{ }^{[\mathrm{b}]}$
\end{tabular}

[a] Determined using 1,3,5-trimethoxybenzene as internal standard. [b] Reaction carried out in MeCN

In sharp contrast with previous study ${ }^{[14]}$, an extra amount of phenylsilane appeared detrimental for the amide bond formation (Table 1, entry 2). Longer reaction time associated to amine excess led to an improved conversion of $74 \%$ (Table 1, entry 4 ). However, a substantial acceleration was observed in the presence of a two-fold excess of phenylacetic acid and a quantitative conversion was reached in only two hours at room temperature (Table 1, entry 6). Additional solvent screening led to an even faster reaction in acetonitrile, giving a complete conversion in only 30 minutes (Table 1 , entry 7). Control reactions with other hydrosilanes $\left(\mathrm{Et}_{3} \mathrm{SiH}, \mathrm{PhMe}_{2} \mathrm{SiH}, \mathrm{PMHS}\right.$, TMDS, $\mathrm{Ph}_{2} \mathrm{SiH}_{2}$ ) did not produce any amide 3. Only hexylsilane was found less reactive providing a $33 \%$ conversion under similar reaction conditions. Efforts to identify a more efficient coupling reagent prompted us to investigate the reactivity of phenylsilane derivatives $\mathbf{4 a - 4 e}$, synthesized according to known procedures (Figure 2). ${ }^{[15]}$
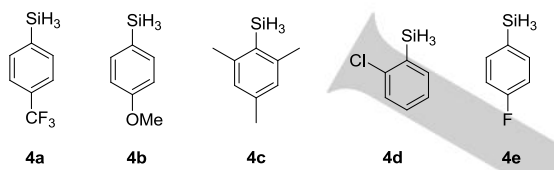

Figure 2. Considered phenylsilane derivatives.

Unfortunately, monitoring reaction progress using ${ }^{1} \mathrm{H}$ NMR, slightly lower performance were showed for hydrosilanes $\mathbf{4 a}$ and $\mathbf{4 b}$ and an absence of reactivity with $\mathbf{4 c}$ and $\mathbf{4 d}$ (see supporting information Figure $\mathrm{S} 1$ ). In our hands, $4 \mathrm{e}$ was found surprisingly too volatile to be evaluated.

Using optimal reaction conditions, various aliphatic, aromatic and heteroaromatic carboxylic acids (1a-f) derivatives were smoothly coupled with primary amines or cyclic secondary amines (Scheme 1).

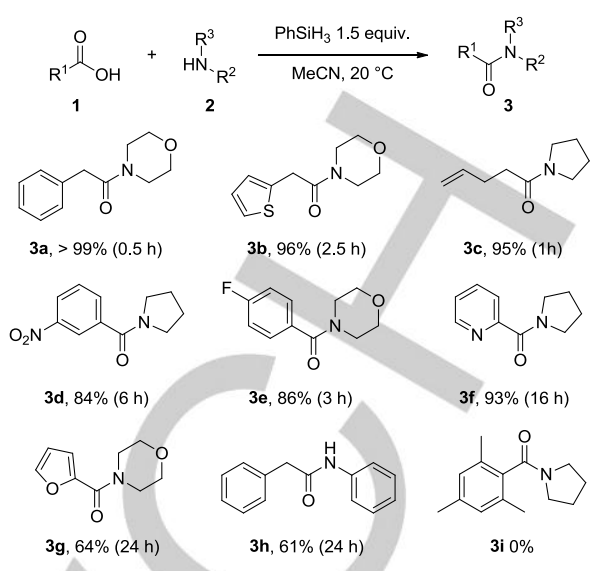

Scheme 1. Substrate scope of phenylsilane promoted amide synthesis. Reaction of $1(2 \mathrm{mmol}), 2(1 \mathrm{mmol})$ and $\mathrm{PhSiH}_{3}(1.5 \mathrm{mmol})$ were carried out in $\operatorname{MeCN}(1 \mathrm{~mL})$ at $20^{\circ} \mathrm{C}$.

As expected, electron rich 2-furancarboxylic acid and less nucleophilic aniline were found to be challenging substrates and moderate $64-61 \%$ yields were obtained after a prolonged reaction time. Also, a limitation was identified with highly hindered mesityl carboxylic acid that gave no detectable amount of amide product.

More challenging peptides couplings were then examined using phenylsilane. Surprisingly, a solvent change to methylene chloride was required, as slightly lower yield of Boc-Phe-PheOMe 7a was obtained with acetonitrile. Additives such as DMAP, DMAPO $^{[16]}$ or sodium bisulfite ${ }^{[17]}$ did not improve the yield. Only one equivalent of potassium cyanide was found to barely improve the yield of the reaction but the acute toxicity of such additive excluded further investigations.

When $\alpha$-amino ester hydrochloride was used as a substrate in the presence of added triethylamine, the yield of Boc-Phe-PheOMe 7 a dropped to $29 \%$. Therefore we investigated the scope of the reaction using $\alpha$-amino esters as free amine. All the reactions proceeded smoothly to afford the desired dipeptides 7 in good to moderate yields. Boc-glycine was efficiently coupled to methyl $\alpha$-amino esters of phenylalanine, proline, valine, methionine, aspartic acid and sarcosine (7b-g, Scheme 2). More significantly, other $\mathrm{N}$-protected $\alpha$-amino acids derived from proline, phenylalanine and tryptophan performed equally well with $62-83 \%$ isolated yields (7h-n, Scheme 2). Under our mild reaction conditions, usual protecting groups were well tolerated, including the versatile Fmoc group as illustrated by the synthesis of Fmoc-Phe-Phe-OMe in $75 \%$ yield $(7 \mathrm{~m}$, Scheme 2). Strongly hindered $O$-protected Boc-threonine and valine delivered peptides 70 and $7 p$, albeit in moderate $55-56 \%$ yields (Scheme 2 ). In contrast, a control reaction with Boc-threonine bearing an unprotected hydroxyl group failed to deliver the corresponding peptide. Importantly, no epimerization was detected when using chiral $N$-protected $\alpha$-amino acids even in the presence of sensitive Boc-phenylglycine as demonstrated with the synthesis of $7 q$ in $57 \%$ yield (Scheme 2 ). 


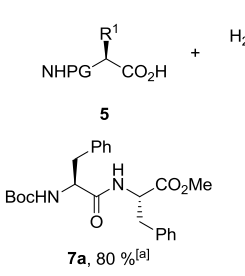

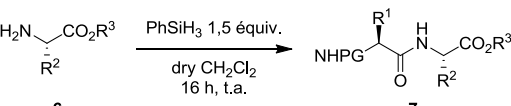$$
6
$$$$
7
$$$$
\text { BocHN } \overbrace{\mathrm{O}}^{\mathrm{N}} \overbrace{\mathrm{Ph}}^{\mathrm{CO}_{2} \mathrm{Me}}
$$$$
7 \mathrm{~b}, 79 \%
$$$$
\prod_{0}^{\mathrm{NochN}} \overbrace{\mathrm{CO}_{2} \mathrm{Me}}
$$$$
\text { 7c, } 73 \%
$$

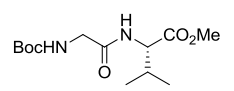

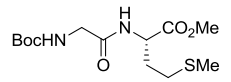
7 e, $72 \%$

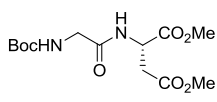
7f, $80 \%$

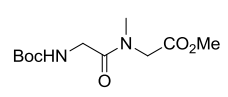

$7 \mathrm{~g}, 79 \%$<smiles>CC(=O)CNC(=O)C1CCCN1C</smiles><smiles>CC(=O)C(C[C@H](C)O)NC(=O)C1CCCN1</smiles>
$7 \mathrm{~h}, 62 \%$ [a]<smiles>CC(=O)CNC(=O)N1CCCN1C</smiles><smiles>CC(C)C(=O)NC(C(C)C)C(C)C</smiles>
$7 \mathrm{k}, 84 \%$ \%[]

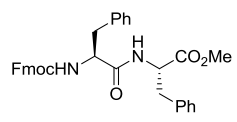

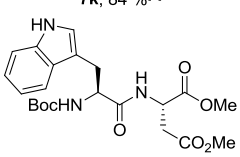

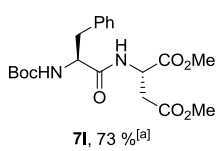<smiles>CNC(C(=O)NC(C(C)=O)C(C)C)C(C)C</smiles>
$70,56 \%$ [a]

$7 \mathrm{~m}, 75 \%^{[\mathrm{a}]}$ $7 \mathbf{n}, 83$ \%[a]

$$
\underset{\substack{\mathrm{Ph} \\ 7 q, 57 \% \text { [a] }}}{\mathrm{Coc}_{\mathrm{H}}} \overbrace{\mathrm{CO}_{2} \mathrm{Me}}^{\mathrm{CO}_{2} \mathrm{Me}}
$$

$$
\underbrace{\mathrm{Bs}, 55 \%}_{7 \mathrm{r}, 48 \%}
$$

Scheme 2. Substrate scope of phenylsilane promoted peptide synthesis Reaction of $N$-protected $\alpha$-amino acid 1 (2 mmol), $\alpha$-amino ester $2(1 \mathrm{mmol})$ and $\mathrm{PhSiH}_{3}(1.5 \mathrm{mmol})$ were carried out in dry $\mathrm{CH}_{2} \mathrm{Cl}_{2}(1 \mathrm{~mL})$ for 16 hours at $20{ }^{\circ} \mathrm{C}$. [a] d.e. $>99 \%$. HPLC data available in supporting information.

Unfortunately, as the peptide chain extend yields plummeted and tripeptides $7 \mathrm{r}$ and $7 \mathrm{~s}$ were obtained in moderate $48 \%$ and $55 \%$ yields, respectively. However, those yields are in line with Charette's study ${ }^{[14]}$ while reactions were run at ambient temperature in our case.

As a case study, Weinreb amide synthesis was also investigated. To the best of our knowledge hydrosilane mediated synthesis of such useful intermediates is unreported and so might represent a useful alternative to well-known procedures. ${ }^{[18]}$ As expected, the use of $\mathrm{N}, \mathrm{O}$-dimethylhydroxylamine was found unreliable since the free amine readily decomposed. As a consequence the reaction was optimized with the corresponding hydrochloride salt. Several aliphatic and electron depleted aromatic carboxylic acids gave the corresponding Weinreb amides in good to moderate $86-44 \%$ yields (8a-e, Scheme 3 ).

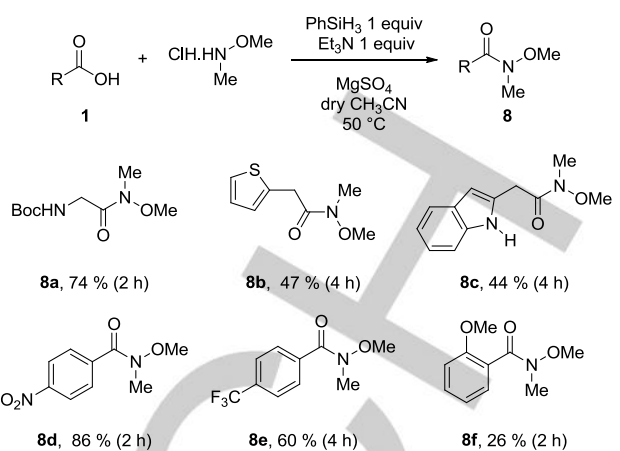

Scheme 3. Substrate scope of phenylsilane promoted Weinreb amide synthesis.

The less electrophilic 2-methoxybenzoic acid reacted sluggishly due to a combination of unfavorable electronic and steric factors (Scheme 3).

The mechanism of amide synthesis involving hydrosilanes is still unclear. Charette conducted a brief mechanistic study and proposed a chemical ligation pathway requiring the addition of both amine and carboxylic acid at the silicon atom followed by the intramolecular addition of silylamine 9 to neighboring silylester. ${ }^{[10 h, 14]}$ However, such mechanism involving the formation of a silanone was later determined thermodynamically unfavorable using DFT calculations. ${ }^{[19]} \mathrm{A}$ related study by Denton supported that phenylsilylester 10 (Figure 3 ) is effective for amide synthesis however in refluxing toluene and with a moderate yield of $64 \% .{ }^{[20 a]}$ The observation that an excess of carboxylic acid significantly bolstered the reaction kinetic suggested than a putative polysilylester intermediate might be responsible for the high reactivity observed at room temperature. Therefore we hypothesized that diester 11 or triester $\mathbf{1 2}$, readily formed by a two-fold or three-fold dehydrogenative addition of carboxylic acid to phenylsilane, might be responsible for the reactivity observed at room temperature.

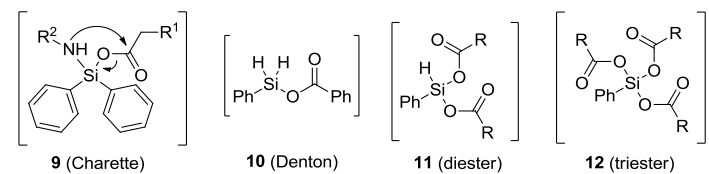

Figure 3. Possible reactive intermediate involved in hydrosilanes mediated amide synthesis.

However, in our hands any effort to isolate reactive esters 11 and 12 failed and systematically ended with polysiloxanes formation. As a surrogate, the acetylation of morpholine $2 \mathrm{a}$ was investigated with various commercially available silyl acetates 13a-c (Scheme 4). 


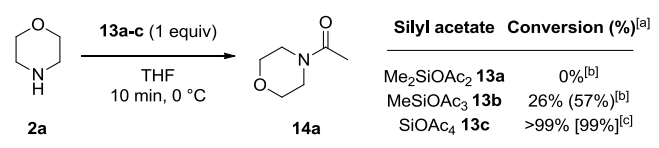

Scheme 4. Silyl acetate reactivity in acetylation reaction. [a] NMR conversion determined using 1,3,5-trimethoxybenzene as internal standard. [b] Conversion after $5 \mathrm{~h}$ at room temperature. [c] Isolated yield.

Interestingly, diacetoxydimethylsilane 13a was found not productive at all: even after 5 hours at room temperature, no trace of amide product was detected by ${ }^{1} \mathrm{H}$ NMR (Scheme 4). On the contrary, triacetoxy(methyl)silane 13b displayed a moderate conversion of $26 \%$ at $0{ }^{\circ} \mathrm{C}$ and more than two-fold increased at room temperature (Scheme 4). Finally, silicon tetraacetate $13 \mathrm{c}$ reacted quantitatively and almost immediately at $0{ }^{\circ} \mathrm{C}$. While a direct comparison is arguable, such results suggest that silicon esters $\mathbf{1 0}$ and $\mathbf{1 1}$ are not responsible for the reactivity observed at room temperature. Indeed it appeared clearly that added acetate groups at the silicon significantly boosted the electrophilicity of the acetyl moiety. This prompted us to rationalize that phenylsilane mediated amide synthesis is likely to occur through putative ester $\mathbf{1 2} .^{[20 b]}$

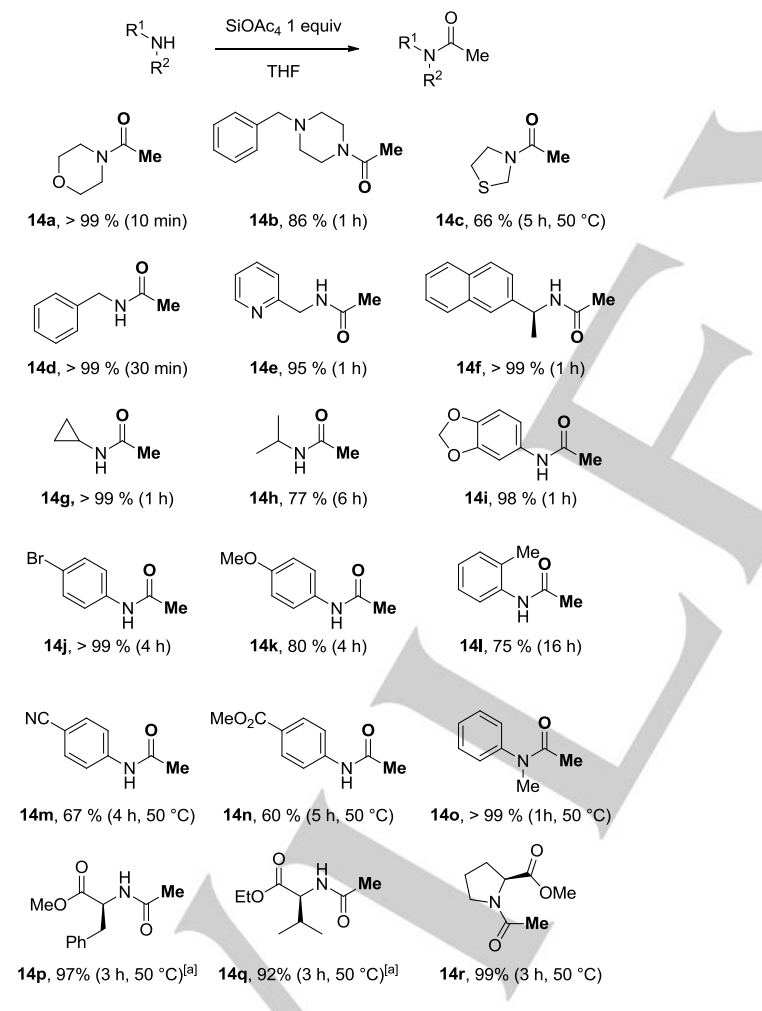

Scheme 5. Substrate scope of silicon tetraacetate promoted acetamide synthesis. Reaction times are not optimized for individual substrates. [a] e.e. > $99 \%$. HPLC data available in supporting information.

To the best of our knowledge, silicon tetraacetate has never been considered so far as a general acetylating reagent of amines. Therefore, its versatility was demonstrated by the synthesis of a range of acetamides under mild conditions and in absence of any base (Scheme 5).
Most amines and anilines gave high yields at room temperature (14a-I, $75-99 \%$ isolated yields) and only electron poor or $\mathrm{N}$-substituted anilines required mild heating to reach reasonable to excellent yields (14m-0, Scheme 5). Additional chiral alpha amino ester were also acetylated without noticeable racemization (14p-r, Scheme 5).

\section{Conclusions}

In conclusion, phenylsilane was reassessed as an efficient amide and peptide coupling reagent. A large scope of dipeptides and two tripeptides was achieved with good to moderate yields. It is worth noting that no side reaction such as epimerization was observed even with phenylglycine derivatives. Comparative experiments using various acetoxysilanes pointed towards phenyltriacyloxysilane as reactive intermediate. Finally, silicon tetraacetate was introduced as an interesting acetylating reagent for amines and anilines that operate in mild conditions and in absence of base.

\section{Acknowledgements}

The authors thank the CNRS, Labex Synorg (ANR-11-LABX0029) for AC fellowship, Normandie université, the Conseil Régional de Normandie and the European FEDER fundings for financial support.

Keywords: hydrosilane $\cdot$ amide $\cdot$ peptide $\cdot$ acetylation $\bullet$ coupling reagent

[1] a) A. Greenberg, C. M. Breneman, J. F. Liebman in The Amide Linkage: Structural Significance in Chemistry, Biochemistry, and Materials Science, Wiley-Interscience, New York, 2000. b) A. R. Chamberlin, Chem. Rev. 1997, 97, 2243-2266. c) K. E. Schwieter, J N. Johnston J. Am. Chem. Soc. 2016, 138, 14160-4169.

[2] T. Wieland, M. Bodanszky, in The World of Peptides: A Brief History of Peptide Chemistry, Springer, 1991

[3] a) S. D.; Roughley, Jordan, A. M. J. Med. Chem. 2011, 54, 3451-3479. b) M. C. Bryan, P. J. Dunn, D. Entwistle, F. Gallou, S. G. Koenig, J. D. Hayler, M. R. Hickey, S. Hughes, M. E. Kopach, G. Moine, P. Richardson, F. Roschangar, A. Steven, F. J. Weiberth, Green Chem. 2018, 20, 5082-5103.

[4] For recent reviews about peptides synthesis see: a) F. Albericio, A. ElFaham, Org. Process Res. Dev. 2018, 22, 760-772. b) S. C. Stolzewand, M. Kaiser, Synthesis 2012, 44, 1755-1777. c) V. Made, S Els-Heindl, A. G. Beck-Sickinge, Beilstein J. Org. Chem. 2014, 10, 1197-. d) E. Valeur, M. Bradley, Chem. Soc. Rev. 2009, 38, 606-631. e) S. B. H. Kent, Chem. Soc. Rev. 2009, 38, 338-351. f) A. El-Faham, F. Albericio, Chem. Rev. 2011, 111, 6557-6602.

[5] V. R. Pattabiraman, J. W. Bode, Nature 2011, 480, 471-479.

[6] For recent reviews about amide bond formation see: a) H. Lunberg, F. Tinnis, N. Selander, H. Adolfsson, Chem. Soc. Rev. 2014, 43, 2714 2742. b) R. Marcia de Figueiredo, J.-S. Suppo, J.-M. Campagne, Chem. Rev. 2016, 116, 12029-12122. c) A. Ojeda-Porras, D. Gamba-Sanchez, J. Org. Chem. 2016, 81, 11548-11555. d) M. T. Sabatini, L. T. Boulton, H. F. Sneddon, T. D. Sheppard, Nat. Catal. 2019, 2, 10-17. e) K Hollanders, B. U. W. Maes, S. A. Ballet, Synthesis 2019, 51, 22612277

[7] a) T. Krause, S. Baader, B. Erb, L. J. Gooßen, Nat. Commun. 2016, 7, 11732-. b) H. Lundberg, F. Tinnis, H. Adolfsson, Appl. Organomet. 
Chem. 2019, 33, e5062. c) H. Lundberg, F. Tinnis, N. Selander, H. Adolfsson, Chem. Soc. Rev. 2014, 43, 2714-2742.

[8] For key references in boron-catalysed amide synthesis see: a) K. Ishihara, S. Ohara, H. Yamamoto, J. Org. Chem. 1996, 61, 4196-4197. b) R. M. Al Zoubi, O. Marion, Hall, D. G. Angew. Chem. Int. Ed. 2008 47, 2876-2879. c) N. Gernigon, R. M. Al Zoubi, D. G. Hall, J. Org Chem. 2012, 77, 8386-8400. d) E. K. W. Tam, Rita, L. Y. Liu, A. Chen, Eur. J. Org. Chem. 2015, 5, 1100-1107. e) T. Mohy El Dine, W. Erb, Y. Berhault, J. Rouden, J. Blanchet, J. Org. Chem. 2015, 80, 4532-4544. f) T. Mohy El Dine, J. Rouden, J. Blanchet, Chem. Commun. 2015, 51, 16084-16087. g) H. Noda, M. Furutachi, Y. Asada, N. Kumagai, M Shibasaki, Nature Chem. 2017, 9, 571-577. h) C. R. Opie, H. Noda, M. Shibasaki, N. Kumagai, Chem. Eur. J. 2019, 25, 4648-4653. i) H. Noda, Y. Asada, M. Shibasaki, N. Kumagai, J. Am. Chem. Soc. 2019, 141, 1546-1554. j) Z. Liu, H. Noda, M. Shibasaki, N. Kumagai, Org Lett. 2018, 20, 612-615. k) D. N. Sawant, D. B. Bagal, S. Ogawa, K. Selvam, S. Saito, Org. Lett. 2018, 20, 4397-4400. I) N. Shimada, M. Hirata, M. Koshizuka, N. Ohse, R. Kaito, K. Makino, Org. Lett. 2019, 21, 4303-4308. m) M. T. Sabatini, L. T. Boulton, T. D. Sheppard, Sci. Adv. 2017, 3, e1701028.

[9] L. Hu, S. Xu, Z. Zhao, Y. Yang, Z. Peng, M. Yang, C. Wang, J. Zhao, J. Am. Chem. Soc. 2016, 138, 13135-13138.

[10] a) T.-H. Chan, L. T. L. Wong, J. Org. Chem. 1969, 34, 2766-2767. b) T.-H. Chan, L. T. L. Wong, J. Org. Chem. 1971, 36, 850-853. c) S. H. Van Leeuwen, P. J. L. M. Quaedflieg, Q. B. Broxterman, R. M. J. Liskamp, Tetrahedron Lett. 2002, 43, 9203-9207. d) T. Tozawa, Y. Yamane, T. Mukaiyama, Chem. Lett. 2005, 34, 1586-1587. e) T. Tozawa, Y. Yamane, T. Mukaiyama, Chem. Lett. 2005, 34, 734-735. f) T. Tozawa, Y. Yamane, T. Mukaiyama, Chem. Lett. 2005, 34, 13341335. g) T. Tozawa, Y. Yamane, T. Mukaiyama, Heterocycles 2006, 67, 629-641. h) S. J. Aspin, S. Taillemaud, P. Cyr, A. B. Charette, Angew. Chem. Int. Ed. 2016, 55, 13833-13837.

[11] D. C. Braddock, P. D. Lickiss, B. C. Rowley, D. Pugh, T. Purnomo, G. Santhakumar, J. F. Fussell, Org. Lett. 2018, 20, 950-953.

[12] Z. Ruan, R. M. Lawrence, C. B. Cooper, Tetrahedron Lett. 2006, 47, 7649-7651. The title «Phenylsilane as an active amidation reagent for the preparation of carboxamides and peptides » is misleading since no peptide synthesis is reported there (following IUPAC peptide definition as "amides derived from two or more amino carboxylic acid molecules").

[13] Typically, 10 equiv of amines and 20 equiv of $\mathrm{PhSiH}_{3}$ were used.

[14] M. Sayes, A. B. Charette, Green Chem. 2017, 19, 5060-5064.

[15] M. D. Visco, J. M. Wieting, A. E. Mattson, Org. Lett. 2016, 18, 2883 2885.

[16] I. Shiina, H. Ushiyama, Y. Yamada, Y. Kawakita, K. Nakata, Chem. Asian J. 2008, 3, 454-461.

[17] B. lorga, J.-M. Campagne, Synlett 2004, 10, 1826-1828.

[18] a) J. I. Levin, E. Turos, S. M. Weinreb, Synth. Commun. 2006, 12, 989993. b) I. Maugras, J. Ponchet, P. Jouin, Tetrahedron 1990, 46, 28072816. c) P. A. Jacobi, W. Zheng, Tetrahedron Lett. 1991, 32, 1279 1282.

[19] a) Y. Y. Jiang, L. Zhu, Y. Liang, X. Man, S. Bi, J. Org. Chem. 2017, 82, 9087-9096. b) B. Hu, Y.-Y. Jiang, P. Liu, R.-X. Zhang, Q. Zhang, T.-T. Liu, S. Bi, Org. Biomol. Chem. 2019, 17, 9232-9242.

[20] a) K. G. Andrews, R. M. Denton, Chem. Commun. 2017, 53, 79827985. A more recent NMR study concluded that amide synthesis did not directly involve monoester 9 or $\mathbf{1 0}$. see b) P. B. White, S. J. Rijpkema, R. P. Bunschoten, J. Mecinović, Org. Lett. 2019, 21, 10111014. 
Entry for the Table of Contents

\section{COMMUNICATION}

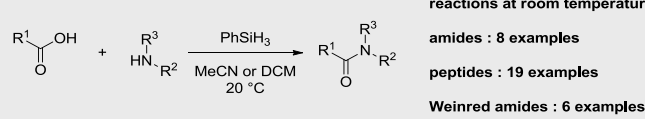

Phenylsilane as been reassed as useful coupling reagent for amides synthesis. Peptides and Weinreb amides are easily obtained under mild conditions in absence of epimzerization even with challenging substrates such as phenylglycine. Further investigation regarding the reactivity of stable acetoxysilanes supported phenylpolyacyloxysilane as key intermediate.
Amides synthesis

Eléonore Morisset ${ }^{[a]}$, Aurélien

Chardon $^{[a]}$, Jacques Rouden ${ }^{[a]}$ and Jérôme Blanchet ${ }^{[a]}$

Page No. - Page No.

Phenysilane and Silicon Tetraacetate: Versatile Promotors for Amide Synthesis. 